\title{
Hubungan antara Penyesuaian Diri dengan Prestasi Akademik Mahasiswa
}

\author{
Abdullah Yunus, Gita Erwilya \\ UIN Sulthan Thaha Saifuddin Jambi \\ Email: abdullahyunus@uinjambi.ac.id
}

\begin{abstract}
Abstrak: Artikel ini dilatarbelakangi oleh fenomena pada mahasiswa baru ketika mulai memasuki perguruan tinggi, transisi dari Sekolah Menengah Atas ke Perguruan Tinggi memunculkan berbagai perubahan secara sosial maupun secara akademik yang akan dihadapi oleh mahasiswa. Tujuan dari penelitian ini adalah untuk mengetahui apakah terdapat hubungan antara penyesuaian diri dengan prestasi akademik mahasiswa fakultas dakwah universitas islam negeri sultan thaha saifuddin jambi. Metode penelitian yang digunakan adalah korelasi multiple yaitu metode yang digunakan untuk mengetahui hubungan antara satu variabel dengan variabel lainnya. Subjek dalam penelitian ini adalah sebanyak 92 orang mahasiswa Fakultas Dakwah Tahun Ajaran 2019. Berdasarkan hasil analisis penelitian didapatkan hasil korelasi yaitu $p=0.005 \leq 0.005$. Hasil yang diperoleh dari analisis data adalah Ho ditolak dan $\mathrm{Ha}$ diterima, sehingga didapatkan hasil bahwa terdapat hubungan antara penyesuaian diri dengan prestasi akademik mahasiswa Fakultas Dakwah Universitas Islam Negeri Sultan Thaha Saifuddin Jambi. Kata-kata kunci : penyesuaian diri, prestasi akademik, Indeks prestasi
\end{abstract}

\section{A. Pendahuluan}

Perkembangan ilmu pengetahuan dan teknologi yang sangat pesat, sehingga membawa kepada moderenisasi disegala bidang. Perkembangan tersebut menjadikan persaingan antar bangsa untuk maju semakin pesat. Hal ini juga memberikan perubahan yang besar terhadap masyarakat Indonesia pada umumnya, perubahan pada tatanan masyarakat, nilai dan moral. Seiring perkembangan tersebut, pendidikan memiliki peran yang penting dalam mempersiapkan SDM unggul ditengah persaingan yang semakin ketat. 
Menurut UU No. 20 Tahun 2003 tentang Sistem Pendidikan Nasional RI menyatakan bahwa: Pendidikan nasional berfungsi untuk mengembangkan kemapuan dan membentuk watak serta peradaban bangsa yang bermartabat dalam rangka mencerdaskan kehidupan bangsa, bertujuan untuk mengembangkan potensi peserta didik agar menjadi manusia yang beriman dan bertaqwa kepada Tuhan Yang Maha Esa, berakhlak mulia, sehat, berilmu, cakap, kreatif, mandiri dan menjadi warga negara yang demokratis dan bertanggung jawab. $^{1}$

Perguruan tinggi merupakan kelanjutan dari pendidikan sekolah menengah atas yang menjadi wadah bagi mahasiswa sebagai kaum intelektual yang mampu berfikir, bertindak dan berpartisipasi aktif dalam mengahadapi moderenisasi ini. Dunia perguruan tinggi tidaklah sama dengan sekolah menengah atas, dimana ketika memasuki perguruan tinggi kita tidak lagi disebut sebagai pelajar melainkan disebut sebagai mahasiswa.

Mahasiswa dituntut untuk mandiri dalam melaksanakan tugasnya dan menyelesaikan tugas-tugas yang telah diberikan oleh dosen, baik itu tugas individu maupun tugas kelompok. Mahasiswa harus mempunyai wawasan yang luas dan pengetahuan akan kemajuan ilmu pengetahuan, sehingga memudahkan dalam penyelesaian tugas yang diberikan dan juga sebagai bekal dalam mengadapi tantangan masa yang akan datang dan mampu kompeten dalam berbagai bidang .

Dalam melihat seberapa jauh pencapaian hasil belajar yang didapatkan oleh mahasiswa melalui tugas-tugas yang diberikan oleh dosen pengampu mata kuliah, dan melihat sejauh mana keaktifan mahasiwa dalam mengikuti kegiatan diskusi didalam kelas, serta keterlibatan mahasiswa dalam kelompok belajarnya, maka dilakukan evaluasi setiap tengah dan akhir semester yaitu dengan

\footnotetext{
${ }^{1}$ Depdiknas, Undang-Undang Sistem Pendidikan Nasional, 2003
} 
melakukan ujian tengah semester (UTS) dan juga ujian akhir semester (UAS) sehingga dapat dilihat hasil belajar yang dicapai oleh mahasiwa.

Proses evaluasi hasil belajar yang dilakukan secara berkesinambungan akan membantu guru/dosen untuk memperoleh kepastian dan kemantapan keberhasilan atau kegagalan proses pembelajaran yang akan digunakan dalam menentukan langkah dan merumuskan kebijakan untuk proses pembelajaran selanjutnya.

Prestasi akademik mahasiwa adalah hasil usaha yang telah dicapai dan dikerjakan oleh mahasiswa yang berkaitan dengan keilmuan yang diberikan oleh dosen. Prestasi belajar dapat dilihat dari Indeks Prestasi Kumulatif (IPK) sebagai bentuk pencapaian mahasiswa terhadap pengetahan dan keterampilan yang dikembangkan dalam mata kuliah yang dipelajari yang dinyatakan dalam bentuk angka, huruf dan kalimat yang mencerminkan hasil akhir pencapaian dalam waktu tertentu.

Berdasarkan data yang didapatkan dari indeks prestasi mahasiswa baru tahun akademik 2019 fakultas dakwah sebanyak 70 (58,82)\% mahasiswa berada pada indeks prestasi dengan kategori tinggi, sedangkan sebanyak 4 (3,37\%) berada pada kategori rendah/tidak lulus.

Penelitian yang dilakukan oleh Putrianji Hendikiawati tentang Analisis Faktor yang Mempengaruhi Indeks Prestasi Mahasiswa menyatakan beberapa faktor utama yang mempengaruhi indeks prestasi mahasiswa adalah manajamen diri dari mahasiswa tersebut, seperti suasana hati, hubungan dengan keluarga, teman maupun dosen, dan kegiatan yang positif, dan faktor utama lainnya yaitu adaptasi diri mhasiswa dengan lingkungannya. ${ }^{2}$

Fakultas dakwah terdiri dari mahasiswa yang berasal dari berbagai daerah, ada yang berasal dari dalam daerah dan ada juga yang berasal dari luar daerah dan juga masing-masing mahasiswa memiliki kemampuan dan keterampilan yang

2 Putriaji Hendikiawati, "Analisis Faktor yanng Mempengaruhi Indeks Prestasi Mahasiswa", Jurnal Matematika, Vol 2, No. 1, 2011, 34 
beragam yang berbeda antara yang satu dengan yang lainnya. Sehinga menghasilkan tindak perilaku dan budaya yang berbeda juga. Mulai dari kebiasaan berbahasa, kebiasaan berkomunikasi maupun kebiasaan dalam bertindak dan berperilaku. dari berbagai latar belakang budaya yang berbeda tentunya juga memengaruhi persfektif dan nilai-nilai yang dianut, serta kontrol emosi yang ditampilkan.

Berdasarkan hasil wawancara secara tidak terstruktur yang dilakukan kepada beberapa mahasiswa fakultas dakwah, diperoleh informasi bahwa tidak semua mahasiswa baru dapat menyesuaikan diri dengan mudah terhadap lingkungannya, sebagaian mahasiswa sulit untuk beradaptasi karena adanya perbedaan budaya, bahasa dan lainnya yang bisa saja dianggap merupakan suatu hal yang bertentangan dari dirinya. Tetapi ada juga mahasiswa yang mudah untuk menyesuaikan dirinya dengan lingkungan.

Masa transisi dari sekolah menengah atas ke perguruan tinggi otomatis akan dihadapkan pada ketidak biasaan dengan situasi baru yang dihadapi yang menuntut mahasiswa untuk mampu mandiri dalam menentukan hal-hal yang berkaitan dengan pembelajarannya. Segala sesuatu yang sedang mengalami atau dalam keadaan perubahan dari suaru situasi ke situasi yang lainnya, akan cenderung menimbulkan goncangan dan permasalahan baru yang dapat berakibat buruk bahkan fatal.

Menurut laporan Wankowwaki lebih dari $60 \%$ mahasiswa tahun pertama meninggalkan dunia kampus tanpa menyelesaikannya. Mayoritas mahasiswa meninggalkan kampus dalam kurun waktu satu sampai dua tahun setelah memasuki dunia kampus. Hal ini dikarenakan adanya indikasi mahasiswa tidak dapat menyesuaiakan diri di kampus. ${ }^{3}$

Penyesuaian diri merupakan hal yang penting bagi mahasiswa, kemampuan penyesuaian diri yang baik dapat membantu mahasiswa dalam mengembangkan

\footnotetext{
${ }^{3}$ Reza Febra Yeni, "Hubungan antara penyesuaian diri dengan prestasi belajar mahasiswa tahun pertama fakultas dakwah dan ilmu komunikasi UIN Imam Bonjol Padang”, Jurnal Bimbingan dan Konseling Islam, Vol. 1 No.1, 2018, 101
} 
diri, dan mampu bersosialisasi dengan baik serta mendapatkan prestasi akademik yang memuaskan. Penelitian yang dilakukan Nasir (dalam ari, 2018 ) pada 106 Mahasiswa Internasional di dua Universitas Negeri di Islamabad menunjukkan bahwa penyesuaian diri dan prestasi akademik memiliki korelasi yang positif dan signifikan yaitu ketika mahasiswa internasional mampu menyesuaikan diri dengan lingkungan di tempat baru dia, maka akan cenderung memiliki prestasi akademik yang bagus dan tinggi, begitupun sebaliknya. ${ }^{4}$

Pada dasaranya orang menyesuaikan diri karena dua alasan utama. Pertama, perilaku orang lain memberikan informasi yang bermanfaat. kedua, kita menyesuaikan diri karena ingin diterima secara sosial, sebagai makhluk sosial tentunya manusia dituntuk dalam kehidupan sehari-hari manusia untuk tidak lepas dari menjalin hubungan dengan yang lain, manusia selalu untuk dapat berpartisipasi dan menyesuaikan diri. Saling berinteraksi anatara satu dengan yang lainnya. karena itu merupakan hal yang sangat penting ketika hidup bermasyarakat, berbangsa dan bernegara.

Allport merumuskan kepribadian manusia sebagai kepribadian adalah organisasi dinamis dari sistem psiko-fisik dalam individu yang turut menentukan cara-cara yang khas dalam menyesuaikan dirinya dengan lingkungannya.

Schneiders (dalam desmita) menyatakan bahwa penyesuaian diri adalah bentuk proses yang melingkupi reaksi mental dan tingkah laku, dimana individu sedang berupaya untuk mengambil keberhasilan dalam mengatasi kebutuhankebutuhan didalam dirinya, ketegangan-ketegangan, konflik-konflik, dan frustasi yang dialaminya, sehingga tingkat keselarasan antara tuntutan dalam diri dengan apa yang diinginkan oleh lingkungan dimana dia tinggal dapat terwujud dengan baik. ${ }^{5}$ Metode penelitian yang digunakan adalah korelasi multiple yaitu metode yang digunakan untuk mengetahui hubungan antara satu variabel dengan

${ }^{4}$ Ari Prasetyo Widiyanto, "Penyesuaian diri dan Prestasi Akademik Dimediasi Oleh Culture Shock pada Mahasiswa Tahun Ajaran 2017-2018 Dari Luar Jawa”, Skripsi, Fakultas Psikologi, Universitas Muhammadiyah Malang, 2018, 3

${ }^{5}$ Desmita, Psikologi Perkembangan, (Bandung, Rosda Karya, 2009), hlm. 192 
variabel lainnya. Subjek dalam penelitian ini adalah sebanyak 92 orang mahasiswa Fakultas Dakwah Tahun Ajaran 2019. Berdasarkan pemaparan di diatas maka artikel ini bertujuan untuk mengetahui apakah terdapat hubungan antara Penyesuaian Diri dengan Prestasi Akademik pada Mahasiswa Fakultas Dakwah UIN STS Jambi.

\section{B. Pembahasan Hasil Penelitian}

Hasil penelitian membuktikan bahwa terdapat hubungan antara penyesuaian diri dengan prestasi akademik mahasiswa fakultas dakwah. Hal ini dilihat dari table Sig. (2-tailed) yaitu $0.05 \leq 0.05$ yang berarti ada hubungan yang signifikan antara kedua variabel. nilai koefisien korelasi antara penyesuaian diri dengan prestasi akademik mahasiswa yaitu 0,292.

Hal ini menunjukkan bahwa hubungan antara variabel $X$ dan variabel $Y$ memiliki hubungan yang lemah. Harga koefisiensi rtabel dengan taraf signifikansi $5 \%$ dan $\mathrm{N}=92$ yaitu sebesar 0,292 . Hasil ini menunjukkan bahwa rhitung lebih besar dari pada rtabel sehingga hipotesis Ho ditolak dan Ha diterima. Ini berarti terdapat hubungan positif yang signifikan antara penyesuian diri dengan prestasi akademik mahasiswa Fakultas Dakwah Universitas Islam Negeri Sulthan Thaha Safuddin Jambi. Sehingga didapatkan hasil semakin besar tingkat penyesuaian diri mahasiswa maka semakin baik nilai indeks prestasi yang didapat oleh mahasiswa.

Berdasarkan penelitian pada mahasiswa fakultas dakwah semester 1(ganjil) Tahun Ajaran 2019 sebanyak 27 (27,17\%) mahasiswa memiliki tingkat penyesuaian diri yang rendah, sebanyak $47(51,08 \%)$ mahasiswa memiliki tingkat penyesuaian diri yang sedang, sebanyak 20 (21,73\%) mahasiswa memiliki tingkat penyesuaian diri yang tinggi.

Dilihat dari pencapaian indeks prestasi mahasiswa terdapat mahasiswa sebanyak $32(34,8 \%)$ yang memiliki indeks prestasi berada pada kategori sangat memuaskan dengan nilai indeks prestasi 3.00 - 3.64, dan sebanyak 60(65,2\%) 
mahasiswa dengan indeks prestasi 3.65 - 4.00 dengan kategori tinggi. berdasarkan hasil indeks prestasi mahasiswa diketahui bahwa tidak terdapat mahasiswa dengan perolehan indeks prestasi $<2.50-2.99$ dengan kategori cukup, dan 0.00 - 1.99 yaitu dengan kategori tidak lulus.

Hal ini mendukung hasil dari analisis korelasi yang menyatakan bahwa terdapat hubungan antara penyesuaian diri dengan prestasi akademik mahasiswa di fakultas dakwah. dilihat dari persentasi data secara umum bahwa banyak diantara mahasiswa yang mampu untuk menyesuaiakan diri diawal tahun pertama memulai perkuliahan dan dari hasil perenstase data indeks prestasi mahasiswa dapat dilihat bahwa tingkat pencapaian indeks prestasi menunjukkan angka yang tinggi.

Hasil penelitian ini diperkuat oleh pendapat Achyar menyatakan bahwa penyesuaian diri dapat meningkatkan efek positif terhadap prestasi belajar peserta didik. Artinya semakin tinggi penyesuaian diri mahasiswa maka semakin tinggi prestasi akademik yang diperoleh mahasiswa.

Hal ini juga selaras dengan penelitian yang dilakukan oleh Risma Anita Puriani dalam penelitiannya "Hubungan antara penyesuaian Diri di Perguruan Tinggi dengan Indeks Prestasi Mahasiswa Bimbingan dan Konseling FKIP Universitas Sriwijaya" dengan perolehan korelasi $\mathrm{rx}_{1} \mathrm{y}=0,609$ dengan taraf signifikan 0,01 $\leq 0,05$ dengan banyak responden $N=105$. Dapat disimpulkan bahwa terdapat hubungan yang signifikan antara penyesuaian diri degan Indeks Prestasi Mahasiswa. Berarti bahwa semakin tinggi tingkat penyesuaian diri mahasiswa maka semakin tinggi indeks prestasi yang diperolehnya. ${ }^{6}$

Schneiders (dalam desmita) menyatakan penyesuaian diri adalah bentuk proses yang melingkupi reaksi mental dan tingkah laku, dimana individu sedang berupaya untuk mengambil keberhasilan dalam mengatasi kebutuhankebutuhan didalam dirinya, ketegangan-ketegangan, konflik-konflik dan frustasi

${ }^{6}$ Risma Anita Puriani, "Hubungan Penyesuaian Diri Di Perguruan Tinggi Dengan Indeks Prestasi Kumulatif Mahasiswa Bimbingan dan Konseling FKIP Universitas Sriwijaya", Konseling Komperehensif, Vol. 4 No 2, 2017, 4 
yang dialaminya. Sehingga tingkat keselarasan antar tuntutan dalam diri dengan apa yang diinginkan oleh lingkungan dimana dia tinggal dapat terwujud dengan baik. $^{7}$

Penyesuian diri mahasiswa mencangkup tiga aspek yaitu penyesuaian secara sosial, penyesuaian secara akademik dan penyesuaian secara fisik dan emosional. Penyesuaian diri secara sosial adalah kemampuan mahasiwa untuk menyelaraskan diri, berinteraksi dengan lingkungannya, membangun hubungan yang harmonis dengan lingkungannya, baik dengan teman-teman, dosen maupun karyawan, sehingga terjalinnya hubungan yang akrab.

Penyesuaian diri secara akademik adalah kemampuan yang dimiliki mahasiswa agar tercapainya kepuasan pribadi terhadap tuntutan akademik, bertanggung jawab dan mampu dalam penyelesaian tugas-tugas yang berkaitan dengan akademik, mampu mengikuti proses pembelajaran didalam kelas, dan mampu untuk memahami materi yang diberikan yang semakin tinggi tingkatannya dan semakin sulit. Dan penyesuaian diri secara fisik dan emosi adalah kemampuan untuk dapat menerima diri secara pribadi dalam mencapai hubungan yang harmonis antara diri dengan lingkungan.

Seorang mahasiswa yang memiliki penyesuaian diri yang baik ialah mereka yang telah mampu belajar bereaksi terhadap diri dan lingkungan dengan caracara yang matang, efesien, dan memuaskan, serta dapat mengatasi konflik mental, frustasi, kesulitan pribadi dan sosial sehingga hubungan antara pribadi dan kebahagiaan timbal balik yang mengandung realisasi dan perkembangan kepribadian. Mahasiswa yang berada pada kategori penyesuaian diri yang sedang adalah mahasiswa ynag sudah mampu menyesuaiakan diri tetapi masih memiliki sikap malasuai (penyesuaian diri yang buruk atau tidak efisien), sedangkan mahasiswa yang berada pada kategori penyesuaian diri yang rendah adalah cederung mahasiswa yang mengalami kesulitan dalam pergaulan, kurang 2009) 192

${ }^{7}$ Desmita, Psikologi Perkembangan: Peserta Didik, (Bandung: PT. Remaja Rosdakarya, 
memiliki rasa percaya diri dan sulit untuk memulai beinteraksi dengan lingkugannya.

Hal ini menjadikan mahasiswa dalam perkuliahannya dapat merasa tentram dan nyaman akan berpengaruh terhadap prestasi akademiknya, sedangkan mahasiswa yang memiliki kemampuan penyesuaian diri kurang, cenderung banyak mengalami masalah dalam pergaulan yang ditandai oleh kurangnya percaya diri, merasa tidak dapat diterima oleh lingkungan, merasa tidak nyaman yang menjadikan munculnya konflik-konflik mental dan kesulitankesulitan lainnya yang berimbas pada prestasi akademik.

\section{Penutup}

Penyesuaian diri secara akademik adalah kemampuan yang dimiliki mahasiswa agar tercapainya kepuasan pribadi terhadap tuntutan akademik, bertanggung jawab dan mampu dalam penyelesaian tugas-tugas yang berkaitan dengan akademik, mampu mengikuti proses pembelajaran didalam kelas, dan mampu untuk memahami materi yang diberikan yang semakin tinggi tingkatannya dan semakin sulit.

Allport merumuskan kepribadian manusia sebagai kepribadian adalah organisasi dinamis dari sistem psiko-fisik dalam individu yang turut menentukan cara-cara yang khas dalam menyesuaikan dirinya dengan lingkungannya.

Berdasarkan pembahasan diatas dapat disimpulkan bahwa terdapat hubungan positif yang signifikan antara penyesuaian diri dengan prestasi akademik pada mahasiswa fakultas dakwah universitas islam negeri Sulthan thaha saifuddin jambi. Hal ini dibuktikan berdasarkan pada hasil analisis korelasi product moment dengan diperoleh nya hasil rhitung=0,292 lebih besar dari pada nilai tabel yaitu 0,207 dengan jumlah sample $\mathrm{N}=92$ mahasiswa Fakultas Dakwah dengan signifikansi 0,005 $<0,005$.

Maka dapat diartikan bahwa ada hubungan yang signifikan antara penyesuaian diri dengan prestasi akademik mahasiswa Fakultas Dakwah 
Universitas Islam Negeri Sulthan Thaha Saifuddin Jambi. Sedangkan berdasarkan data penyesuaian diri yang diolah melalui program SPSS versi 16.0, maka diperoleh hasil tingkat penyesuaian diri pada mahasiswa Fakultas Dakwah Universitas Islam Negeri Sulthan Thaha Saifuddin Jambi yaitu dari 92 mahasiswa, terdapat sebanyak $27(27,17 \%)$ mahasiswa memiliki tingkat penyesuaian diri yang rendah, sebanyak 47 (51,08\%) mahasiswa memiliki tingkat penyesuaian diri yang sedang, sebanyak $20(21,73 \%)$ mahasiswa memiliki tingkat penyesuaian diri yang tinggi.

Kemudian, berdasarkan hasil pengolahan data prestasi akademik mahasiswa yang dirujuk dari Indeks Prestasi Mahasiswa diperoleh hasil sebanyak 60 (65,2\%) mahasiswa dengan Indeks Prestasi 3.65 - 4. 00 dengan kategori cumlaude, dan sebanyak $32(34,8 \%)$ mahasiswa dengan indeks prestasi 3.00 3.64 dengan kategori sangat memuaskan.

Hasil penelitian ini diperkuat oleh pendapat Achyar menyatakan bahwa penyesuaian diri dapat meningkatkan efek positif terhadap prestasi belajar peserta didik. Artinya semakin tinggi penyesuaian diri mahasiswa maka semakin tinggi prestasi akademik yang diperoleh mahasiswa.

\section{Daftar Pustaka}

Al-Qur'an dan Terjemahannya, 49:13

Arifin, dkk, 2016, "Hubungan Kemapuan Penyesuaian Diri dan Pola Berpikir dengan Kemandirian Belajar Serta Dampaknya Pada Prestasi Akademik Mahasiswa", Jurnal Pendidikan, Vol. 01 No. 10

Arikunto Suharsimi, 2013, Prosedur Penelitian: Suatu Pendekatan Praktik, Jakarta, PT.Rineka Cipta, 2013

Basri Hasan, 2012, Prestasi Akademik Mahasiswa Ditinjau Dari Kemampuan Literasi Media, Jurnal Dakwah, Vol. XIII No. 01

Buku Pedoman IAIN Jambi Tahun Akakdemik 2016-2017

Depdiknas,2003, Undang-Undang Sistem Pendidikan Nasional 
Desmita, 2009, Psikologi Perkembangan, Bandung, Rosda Karya

Desmita, 2009, Psikologi Perkembangan: Peserta Didik, Bandung, PT. Remaja Rosdakarya

Dika dkk, 2010, Hubungan antara Penyesuaian Diri terhadap Tuntutan Akademik dengan Kecenderungan Stres pada Mahasiswa Fakultas Kedokteran Universitas Hang Tuah Surabaya, Jurnal, INSAN, Vol. 12 No. 03

Djazari, Endra, 2011, Evaluasi Prestasi Belajar Mahasiswa Program Kelanjutan Studi Jurusan Pendidikan Akutansi Dilihat Dari IPK D3 Dan Asal Perguruan Tinggi, Jurnal Pendidikan Akuntasi Indonesia, Jurnal, Vol. IX No.2

Dokumentasi Humas dan Protokol Fakultas Dakwah, Softfile Visi, Misi dan Program Fakultas Dakwah UIN STS Jambi.

Dokumentasi Wakil Dekan I Fakultas Dakwah, Softfile Sejarah Fakultas Dakwah UIN STS Jambi

Edy Supriyadi, 2014, SPSS + Amos, Bogor, In Media

Faperta UNPAD, Indeks Prestasi Kumulatif (IPK), diaskes melalui http://www.faperta.unpad.ac.id/akademik/pbm-dan-tata-tertib/evaluasihasil-belajar/15-indeks-prestasi-kumulatif-ipk.html Hosnan, 2016, Psikologi Perkembangan Peserta Didik, Bogor, Ghalia Indonesia Irham \& Novan, 2017, Psikologi Pendidikan, Jogjakarta, AR-RUZZ MEDIA Joko Ade,2014, Kompas Teknik Pengambilan Sample, Bogor, In Media Jonathan dan Hendra, 2017, Prosedur-Prosedur Populer Statistik untuk Analisis Data Riset Skripsi, Yogyakarta, Gava Media Kasiram, Moh, 2018, Metodologi Penelitian, Malang: UIN-Malang Pers Lia Amalia, 2013, "Menjelajahi Diri Dengan Teori Kepribadian Carl Rogers", Jurnal $M \cup A D D I B$, Vol. 03, No. 01

Lutfiyah, Muh Fitrah, 2017, Metodologi Penelitian (penelitian kualitatif, tindakan kelas, dan studi kasus), Jawa Barat, CV Jejak 
Nengah I, 2012, "Peranan Bakat Kinestetik Dalam Meningkatkan Prestasi Belajar Mahasiswa Fakultas Seni Pertunjukan Institut Seni Indonesia Denpasar" Jurnal PRASI, Vol. 07 No.14

Rini, Ghufron, 2010, Teori-Teori Psikologi, Jogjakarta, Ar-Ruz Media 